\title{
Calmodulin-Dependent Cyclic Nucleotide Phosphodiesterase in Human Cerebral Cortex and Glioblastoma Multiforme
}

\author{
Sumeer Lal, Rajala V.S. Raju, Robert J.B. Macaulay and Rajendra K. Sharma
}

\begin{abstract}
Background: Calmodulin-dependent cyclic nucleotide phosphodiesterase (CaMPDE) has been extensively studied and characterized in normal mammalian tissues; however very little is known about this enzyme in human brain tumors. It has been established that high levels of this enzyme exist in non-central nervous system tumors, PDE inhibitors or cAMP analogues have been used to treat them. This study has examined the levels of CaMPDE in glioblastoma multiforme from six patients and has compared these to the levels of CaMPDE in four patients with normal cerebral tissue. In addition, an enzyme immune assay method (EIA) was developed in this study for the detection of CaMPDE in human cerebral tissue. This method is proposed to be used as an adjunct to the spectrophotometric method presently utilized. This would be beneficial in cases where small tissue samples, for example in stereotactic biopsy, are available. Methods: The CaMPDE activity and corresponding levels of expression in cerebral tissue from temporal lobectomies and both surgical extraction or stereotactic biopsy in patients with primary tumors were determined by spectophotometric and EIA, respectively. The EIA was developed from the production of a polyclonal antibody against bovine brain $60 \mathrm{kDa}$ CaMPDE isozyme. Cross reactivity of the antibody with human was confirmed using transblot and immunohistochemistry. Results: Utilising the EIA, there was found to be significant reduction in both catalytic activity $(p<0.001)$ and in quantitative protein expression $(p<0.001)$ in glioblastoma multiforme from patients when compared to normal cerebral cortex. Immunoblotting experiments and immunohistochemistry demonstrated that CaMPDE in glioblastoma multiforme failed to react with a polyclonal antibody raised against bovine brain $60 \mathrm{kDa}$ CaMPDE isozyme, whereas the enzyme from normal tissue reacted with antibody. Conclusions: Contrary to other studies on non-CNS tumors, the catalytic activity and the protein expression of CaMPDE is reduced in glioblastoma multiforme. The EIA method is a more sensitive in detecting CaMPDE than in the spectrophotometric method, especially when a small amount of tissue is available. Immunohistochemistry and the EIA may be useful in the future to use as markers for other types of brain tumors and not for glioblastoma multiforme as demonstrated.
\end{abstract}

RÉSUMÉ: Nucléotide phosphodiestérase cyclique dépendante de la calmoduline dans le cortex cérébral humain et le glioblastome multiforme. Introduction: La nucléotide phosphodiestérase cyclique dépendante de la calmoduline (CaMPDE) a été étudiée et caractérisée dans les tissus normaux de mammiferes. Cependant, on connaît peu de choses sur cet enzyme dans les tumeurs cérébrales. Il a été établi que des niveaux élevés de cet enzyme sont présents dans des tumeurs autres que celles du système nerveux central et l'utilisation d'inhibiteurs de la PDE ou d'analogues de l'AMPc ont été utilisés pour traiter ces tumeurs. Dans cette étude, nous examinons les niveaux de CaMPDE dans des glioblastomes multiformes provenant de six patients et nous les comparons aux niveaux de CaMPDE dans des tissus cérébraux normaux provenant de quatre patients. De plus, nous avons développé une méthode de dosage immuno-enzymatique (DIE) pour détecter la CaMPDE dans le tissu cérébral humain. Nous proposons que cette méthode soit utilisée comme méthode d'appoint à la méthode spectrophotométrique utilisée présentement. Ce serait particulièrement utile quant l'échantillon de tissu est petit, lors d'une biopsie stéréotaxique par exemple. Méthodes: Nous avons déterminé l'activité de la CaMPDE et les niveaux correspondants de son expression dans le tissu cérébral provenant de lobectomies temporales et d'exérèses chirurgicales ou de biopsies stérétaxiques, chez des patients porteurs de tumeurs primitives, au moyen de la spectrophotométrie et du DIE respectivement. Le DIE a été développé à partir d'un anticorps polyclonal dirigé contre un isozyme de la CaMPDE de 60kDa de cerveau bovin. La réactivité croisée de l'anticorps avec le matériel humain a été confirmée au moyen de buvardages et d'immunohistochimie. Résultats: L'étude au moyen du DIE a montré une diminution significative de l'activité catalytique $(p<0.001)$ et de l'expression de la protéine ( $p<0.001)$ dans les glioblastomes multiformes de patients comparés a du tissu cortical normal. Les études par buvardage immunologique et par immunohistochimie ont montré que la CaMPDE dans le glioblastome multiforme ne réagit pas avec un anticorps polyclonal dirigé contre l'isozyme de CaMPDE de 60kDa de cerveau bovin alors que l'enzyme du tissu normal réagissait avec l'anticorps. Conclusions: Contrairement à d'autres études sur les tumeurs situées hors du système nerveux central, l'activité catalytique et l'expression protéique de la CaMPDE est diminuée dans le glioblastome multiforme. La méthode de DIE est plus sensible pour détecter la CaMPDE que la méthode spectrophotométrique, surtout sur de petits échantillons de tissu. L'immunohistochimie et le DIE peuvent être utiles à l'avenir comme marqueurs pour d'autres types de tumeurs cérébrales et non pour le glioblastome multiforme comme nous l'avons démontré.

Can. J. Neurol. Sci. 1996; 23: 245-250

It has been evident for some time that cyclic nucleotides play a role in cell growth regulation and that this role may be altered in diseases characterized by unregulated cell growth, such as cancer. This altered role appears to be related to change in cyclic nucleotide levels resulting from corresponding changes in activity of synthetic enzymes (cyclases) and/or hydrolytic enzymes (phosphodiesterases). ${ }^{1-6}$
From the Division of Neurosurgery, Department of Surgery (S.L.); Department of Pathology and Saskatoon Cancer Centre (R.V.S.R., R.J.B.M., R.K.S.) College of Medicine, Royal University Hospital, University of Saskatchewan, Saskatoon. RECEIVED FEBRUARY 6, 1996. ACCEPTED IN FINAL. FORM JUNE 21, 1996.

Reprint requests to: Dr. R.K. Sharma, Department of Pathology, University of Saskatchewan, B419 Health Science Building, 107 Wiggins Road. Saskatoon. Saskatchewan, Canada S7N 5E5 
The importance of cyclic nucleotides as second messengers is well established in the central nervous system. ${ }^{6}$ These components of the signal transducing system play an integral role in the regulation of gene transcription, action potential propagation, postsynaptic potential, cytoskeleton function, neurotransmitter biosynthesis, protein production, cell proliferation and a host of other functions in the neuron. ${ }^{6}$ Since there are close functional interrelationships between receptors, second messengers and genes, ${ }^{7}$ any disturbances of the components of this signal transducing system could potentially lead to uncontrolled cell proliferation and the development ultimately of cancer. The cyclic nucleotide phosphodiesterases have been studied in a variety of tumors, for example: leukemic lymphocytes and lymphoblasts, ${ }^{8,9}$ Hodgkin's disease, ${ }^{10}$ hepatomas, ${ }^{11.12}$ neuroblastoma ${ }^{13}$ and breast cancer. ${ }^{14} \mathrm{Ca}^{2+}$ and the signalling enzymes directly activated by $\mathrm{Ca}^{2+}$ or by $\mathrm{Ca}^{2+}$ binding signaltransducing proteins, such as calmodulin-dependent cyclic nucleotide phosphodiesterase (CaMPDE), are principal players in most of these signals.

Kakiuchi and Yamazaki ${ }^{15}$ were the first to demonstrate the existence of a $\mathrm{Ca}^{2+}$-dependent cyclic nucleotide phosphodiesterase in rat brain. In addition, Kakiuchi et al ${ }^{16}$ discovered an endogenous brain protein factor which could enhance the $\mathrm{Ca}^{2+}$ sensitivity of the enzyme. Independently, Cheung ${ }^{17}$ established the existence of a protein activator in bovine brain which stimulated the cyclic nucleotide phosphodiesterase activity several-fold; Cheung coined the term "calmodulin (CaM)" for this protein activator. Stimulation of the phosphodiesterase activity required the presence of both $\mathrm{Ca}^{2+}$ and CaM. ${ }^{18}$ The activity of calmodulin-dependent cyclic nucleotide phosphodiesterase (CaMPDE) was found to be widely distributed in mammalian tissues and other eukaryotes (see reviews). ${ }^{19-21}$

CaMPDE is one of the most intensively studied and best characterized phosphodiesterases. Initially, it was thought that a single form of the enzyme existed in all tissues; ${ }^{22}$ however, over the years it has become clear that CaMPDE exists as tissue-specific isozymes ${ }^{23-29}$ which have different molecular weights, as well as distinct catalytic and regulatory properties $^{21.30}$ Bovine brain $60 \mathrm{kDa}$ CaMPDE isozyme, bovine heart CaMPDE and bovine lung CaMPDE isozymes are almost identical in terms of immunological properties; however, they are differentially regulated by $\mathrm{CaM}$ and $\mathrm{Ca}^{2+} .{ }^{30}$ In addition, the main difference in the regulation of CaMPDE isozymes appears to be their response to phosphorylation. The heart and brain $60 \mathrm{kDa}$ CaMPDE isozymes are substrates of the cAMPdependent protein kinase, ${ }^{24.31 .32}$ whereas the brain $63 \mathrm{kDa}$ isozyme is phosphorylated by CaM-dependent protein kinases in a $\mathrm{Ca}^{2+}-\mathrm{CaM}$ dependent manner. ${ }^{33-35}$

In this communication we describe the development of an EIA method for CaMPDE. We then document the level of CaMPDE in normal human temporal lobe tissue and compare the results with a malignant brain tumor called glioblastoma multiforme, using both the spectrophotometric method and the EIA. We further demonstrate that the use of the EIA method in cerebral tumors may be an alternative method to measure CaMPDE in cerebral tumors, especially when small amounts of tissue are available.

\section{MATERIALS AND METHODS}

Cyclic AMP and snake venom 5'-nucleotidase were obtained from Sigma. General laboratory chemicals were obtained from Sigma Chemical Co., Fischer and BDH. Bovine brain calmodulin and CaMPDE was purified as described by Sharma and Wan. ${ }^{36}$

\section{Production of the Polyclonal Antibody Against CaMPDE 60 kDa Bovine Brain CaMPDE}

All experiments met with the approval of the University of Saskatchewan animal care committee. Antibodies were raised in New Zealand white rabbits given multiple subcutaneous injections of $50 \mu \mathrm{g}$ of bovine brain $60 \mathrm{kDa}$ CaMPDE isozyme emulsified with complete Freund's adjuvant at multiple sites. The first bleed was done on the 36th day and two boosters were given with the same amount of antigen with incomplete Freund's adjuvant, one on the 37th day and the other on the 56th day respectively. Subsequent bleeds were done on the 55th and 60 th day. The sera were separated from the blood samples and stored at $-20^{\circ} \mathrm{C}$ until used. The antibody titer was determined using the Elisa assay. ${ }^{37}$ The antibody was purified through a protein A Sepharose-4B column $(7.5 \times 1.5 \mathrm{~cm})$, prequilibrated with $100 \mathrm{mM}$ Tris- $\mathrm{HCl}, \mathrm{pH} 8.0$. After application, the column was washed with $100 \mathrm{mMTris}-\mathrm{HCl}, \mathrm{pH} 8.0$, followed by elution of bound $\mathrm{IgG}$ with $100 \mathrm{mM}$ glycine, $\mathrm{pH} 2.5$. Immediately after elution, the $\mathrm{pH}$ was adjusted to 8.0 with $1 \mathrm{M}$ Tris, and the immunoglobulin was dialysed against phosphate-buffered saline overnight. The dialyzed sample was stored at $-70^{\circ} \mathrm{C}$ in small aliquots at $0.9 \mathrm{mg}$ of protein $/ \mathrm{ml}$.

\section{Sample Collection and Preparation of the Tissue}

Cerebral tissue was removed during temporal lobectomy for epilepsy (4 patients) and surgical extraction or stereotactic biopsy in patients with clinical and radiological evidence of a primary brain tumor (30 patients, 6 with glioblastoma multiforme). Specimen samples were sent for pathological diagnosis. The remaining tissue was either frozen at $-70^{\circ} \mathrm{C}$ or processed immediately. The tissue was homogenized using a Polytron homogeniser for $3 \mathrm{~min}$ in 2 volumes of ice cold homogenizing buffer $(20 \mathrm{mM}$ Tris- $\mathrm{HCl}, \mathrm{pH} 7.5,2 \mathrm{mM}$ EDTA, containing 10 $\mu \mathrm{g} / \mathrm{ml}$ leupeptin, $200 \mathrm{mg} / \mathrm{ml}$ benzamidine, $0.2 \mathrm{mM}$ phenylmethylsulfonyl fluoride (PMSF), $10 \mathrm{mM}$ 2-mercaptoethanol and $0.1 \mathrm{mM}$ EGTA). The homogenate was centrifuged at $10,000 \mathrm{~g}$ for $30 \mathrm{~min}$, and the supernatant was dialysed overnight against Buffer A (20 mM Tris- $\mathrm{HCl}, 1 \mathrm{mM}$ imidazole, $1 \mathrm{mM}$ magnesium acetate, pH 7.0 containing $0.2 \mathrm{mM}$ PMSF, $0.1 \mathrm{mM}$ EGTA and $10 \mathrm{mM}$ mercaptoethanol). After dialysis, the supernatant was again centrifuged for 5 minutes at $14,000 \mathrm{~g}$. In this paper the term "normal tissue" refers to human brain tissue taken from patients that did not have brain tumors.

\section{Assay of Phosphodiesterase}

CaMPDE activity was measured at $\mathrm{pH} 7.5$ at $30^{\circ} \mathrm{C}$, as described by Sharma and Wang. ${ }^{38}$ The reaction mixture contained $40 \mathrm{mM}$ Tris- $\mathrm{HCl}, 40 \mathrm{mM}$ imidazole $5 \mathrm{mM}$ magnesium acetate, $\mathrm{pH} 7.5,0.5$ unit of 5'-nucleotidase, $1.2 \mathrm{mM}$ cyclic AMP, and either $0.1 \mathrm{mM} \mathrm{Ca}^{2+}$ or $0.1 \mathrm{mM}$ EGTA (basal activity) and other components as described in figure legends, in a total volume of $0.45 \mathrm{ml}$. Reactions were carried out for 30 minutes at $30^{\circ} \mathrm{C}$. One unit of phosphodiesterase activity is defined as the 
amount of enzyme which, when fully activated, hydrolyses 1 $\mu \mathrm{mol}$ of cyclic nucleotide/min at $30^{\circ} \mathrm{C}$.

\section{Enzyme Immunoassay (EIA) for CaMPDE}

An ElA was performed in 96 well, flat bottom plates (Falcon: Becton Dickson Labware, Lincoln Park, New Jersey, USA). Tissue samples were plated at $100 \mathrm{ng}$ protein $/ 100 \mu \mathrm{l}$ in coating buffer (sodium bicarbonate $0.5 \mathrm{M}, \mathrm{pH} 9.6$ ) and incubated at $4^{\circ} \mathrm{C}$ overnight. The plate was washed five times with 0.01 $\mathrm{M}$ phosphate buffer saline, containing $0.05 \%$ Tween-20 (PBSTween 20), at pH 7.4. Next, non-specific binding with $200 \mu \mathrm{l}$ of 5\% BSA for 2 hrs was done and washed with PBS-Tween 20. Incubation with $1.00 \mu \mathrm{l}$ of 1:2500 PDE polyclonal antibody for 1 hour at $37^{\circ} \mathrm{C}$ was then done followed by a repeat washing with PBS-Tween 20, five times. Incubation with conjugated goat anti-rabbit IgG (Biorad Laboratories, Hercules CA) at a 1:2500 dilution then was carried out at $37^{\circ} \mathrm{C}$. After washing, plate color was developed with Peroxidase Substrate System (Biorad Laboratories), and was read at $415 \mathrm{~nm} 20$ minutes later. Phosphodiesterase levels in the samples were determined from a standard curve obtained from plating known concentrations of purified bovine brain $60 \mathrm{kDa}$ CaMPDE isozyme. Background was evaluated using pre-immune serum. One absorbance of the reaction at $415 \mathrm{~nm}$ read $0.28 \mathrm{pmol}$ of purified $60 \mathrm{kDa}$ CaMPDE isozyme protein.

\section{Immunoblotting}

Proteins were transferred from unstained SDS-gels to nitrocellulose paper, soaked in transblot buffer (25 mM Tris pH 8.0, $192 \mathrm{mM}$ glycine, $20 \%$ methanol, and $0.1 \%$ SDS), for one hour at 55 amps. After washing with immunoblot buffer $(20 \mathrm{mM}$ Tris- $\mathrm{HCl}, \mathrm{pH} 7.5 ; 500 \mathrm{mM} \mathrm{NaCl}$ ), nitrocellulose paper was incubated with blocking buffer (3\% BSA/Immunoblot buffer, containing $0.02 \%$ sodium azide), at room temperature to block non-specific binding. After washing in immunoblot buffer for 10 minutes, the blot was incubated with the polyclonal antibody against CaMPDE, 1:1000 diluted in blocking buffer, at room temperature for $3 \mathrm{~h}$. The blot then was washed in immunoblot buffer containing $0.05 \%$ Tween-20 for 20 minutes, repeated three times and again with immunoblot buffer for 20 minutes. The blot was incubated with the secondary antibody (anti-rabbit IgG-conjugated horseradish peroxidase, diluted 1:1000 with immunoblot buffer $/ 1 \%$ BSA, for 2 hours. After repeat washing with immunoblot buffer $/ 0.05 \%$ Tween-20, the transblot was developed with Biorad HRP color system (Biorad Laboratories, Hercules CA).

\section{Immunohistochemistry}

To establish the validity and immunostaining characteristics of the A6 (monoclonal) antibody ${ }^{26}$ several dilutions were assessed on sections of hippocampus and striatum in normal human brain specimens; the best signal to background ratio was obtained with 1:1000 dilution. The distribution of expression was then assessed from specimens obtained. Formalin-fixed, paraffin-embedded material was used in all cases; paraformaldehyde fixation did not alter the pattern or intensity of staining with the antibody.

Six $\mu \mathrm{m}$ sections on 3-aminopropyltriethoxysilane-coated slides were dried overnight at $37^{\circ} \mathrm{C}$. They were deparaffinized and partially hydrated to $70 \%$ ethanol. Endogenous peroxidase was abolished with $\mathrm{H}_{2} \mathrm{O}_{2}$ in methanol for $10 \mathrm{~min}$. After washing, microwave antigen retrieval was performed in $10 \mathrm{mM}$ citrate buffer, $\mathrm{pH} 4.0$ with 3 cycles of $5 \mathrm{~min}$ each at $400 \mathrm{~W}$. After cooling for $20 \mathrm{~min}$, slides were places in a PBS bath. Following protein suppression of non-specific binding sites, the A6 antibody was applied to the tissue sections at 1/1000 dilution and incubated overnight at $4^{\circ} \mathrm{C}$. After equilibrating to room temperature, detection was facilitated using the DAKOLSAB (streptavidin/biotin) kit. The reaction was visualized with $0.03 \%$ diaminobenzidine as the chromagen. A light Harris haematoxyin counter stain was applied; after bluing, the slides were dehydrated, cleared and mounted.

\section{Other Methods}

Gel Electrophoresis-Polyacrylamide (10\%) gel electrophoresis in the presence of SDS was carried out according to the procedure of Laemmeli. ${ }^{39}$ Coomassie Blue was used to visualize the protein bands on the gel. Protein concentration was determined by the method of Bradford,,$^{40}$ using bovine serum albumin as a standard.

\section{Results}

The specificity of the anti-CaMPDE was carried out by Western blotting using purified proteins: $60 \mathrm{kDa}$ and $63 \mathrm{kDa}$ CaMPDE isozyme from bovine brain ${ }^{26}$ and high molecular weight calmodulin binding proteins from bovine heart. ${ }^{41}$ Only the $60 \mathrm{kDa}$ CaMPDE isozyme was detected on the immunoblot (data not shown). The use of the polyclonal antibody against bovine brain $60 \mathrm{kDa}$ CaMPDE was used to characterize the human brain CaMPDE. Polyclonal antibody, which reacts with $60 \mathrm{kDa}$ CaMPDE isozyme from bovine brain was shown to cross-react with the human brain tissue (Figure 1, lane 1 versus 3).

Under denaturing conditions, the normal human brain CaMPDE was found to have an apparent subunit molecular mass close to $60 \mathrm{kDa}$ (Figure 1, lane 3). Native molecular weight of human brain CaMPDE was also determined by gel filtration column chromatography on S-200 Sephacryl revealing an apparent molecular mass of $124 \mathrm{kDa}$ (data not shown). This suggests that the enzyme is a dimeric protein composed of two identical subunits (Figure 1, lane 1). Although our data do not include specific gene sequencing, the transblot could suggest that interspecies homology does exist for CaMPDE. The ability of the antibody, raised against bovine brain 60 $\mathrm{kDa}$ CaMPDE, to cross react with human CaMPDE strengthens its use in the enzyme immunoassay method and in immunochemistry.

Temporal cortex grey and white matter samples and tumor samples from patients with glioblastoma multiforme were plated and incubated with antisera. These results suggest that CaMPDE activity and enzyme expression is low in tumor samples compared to the normal tissue (Table). The protein expression in tumor sample found to be $0.164 \mathrm{nmol} / \mathrm{g}$ tissue, which was very close to background, whereas in the normal tissue the enzyme expression was observed $0.525 \mathrm{nmol} / \mathrm{g}$ tissue $(p<0.001)$.

In order to ascertain the sensitivity of the EIA method, transblot and immunochemistry methods were utilized. Interestingly, the transblot indicated that the antibody against $60 \mathrm{kDa}$ 


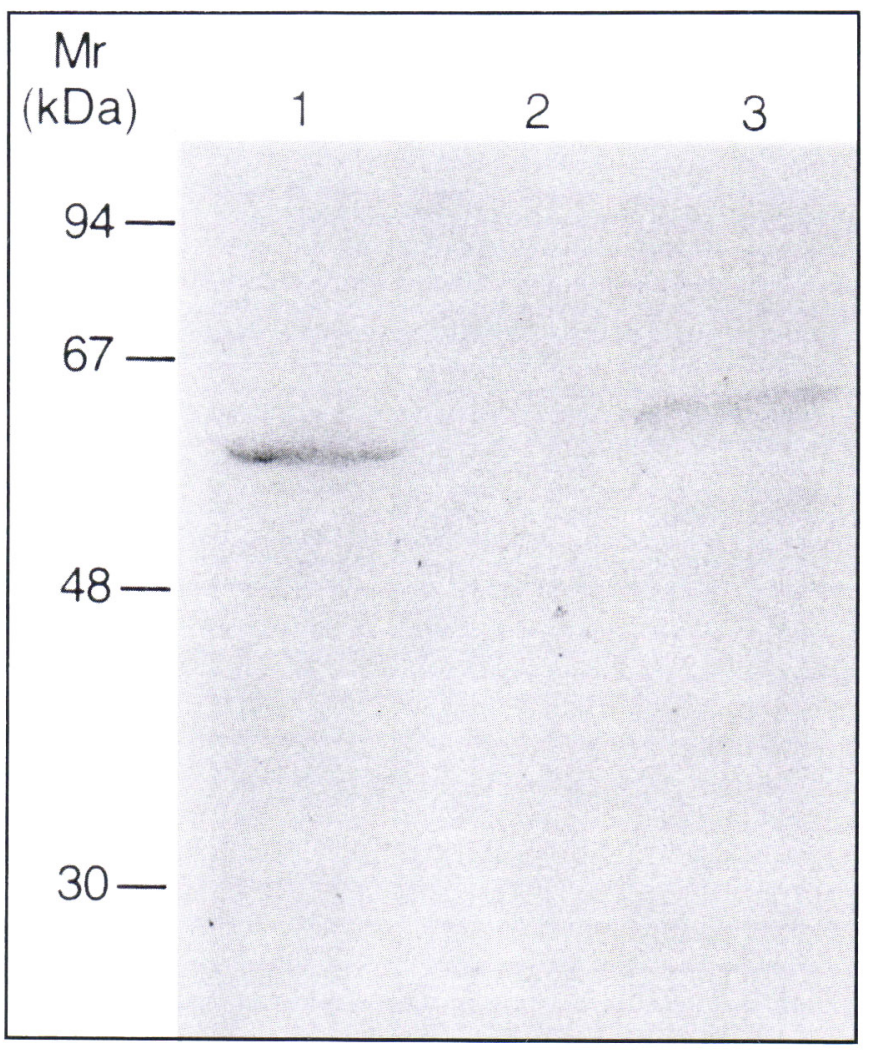

Figure 1: Western blot showing the specificity of $60 \mathrm{kDa} C \mathrm{Ca}+-\mathrm{calmod}$ ulin-dependent phosphodiesterase (CaMPDE) in normal bovine brain and normal human cortex. The samples were subjected to $10 \%$ SDSPAGE and transblotted onto a nitrocellulose membrane as described under "Materials and Methods". Lane 1, bovine brain homogenate (50 $\mu \mathrm{g} /$ well $) ; 2$, glioblastoma multiforme $(50 \mu \mathrm{g} /$ well $) ; 3$, normal human cortex $(50 \mu \mathrm{g} /$ well $)$.

CaMPDE isozyme recognized only the CaMPDE in the normal tissue (Figure 1, lane 3) and failed to recognize the CaMPDE in glioblastoma multiforme cases (Figure 1, lane 2). This occurred with varying concentrations of both antigen and the antibody and suggests that the enzyme is not expressed in glioblastoma multiforme; however, the spectophotometric method did demonstrate very low activity (Table).

The results from the transblot were further substantiated by using immunochemistry. In Figure 2, normal human temporal cortical neurons and dendrite/axonal endings demonstrate strong cytoplasmic labelling with the antibody used in our EIA assay, whereas in Figure 3, glioblastoma cells failed to react effectively with the antibody. Entrapped neurons in this sample showed some immunoreactivity.

\section{Discussion}

In glioblastoma multiforme, the pathological diagnosis is dependent on the presence of focal necrosis. ${ }^{42,43}$ The failure of the antigen-antibody recognition in the immunoblotting for glioblastomas may be attributable to the extensive proteolytic activity of the tissues. This degradation may have altered the epitope significantly so that the antibody would be unable to recognize it; however, this would not account for the low expression seen by immunohistochemistry. The latter results suggest that there may be alternative explanations of the absence of reactivity in the glioblastoma multiforme. Glioblastoma multiforme is a proliferation of neoplastic astrocytes. It has been established that the predominant cell containing PDE in the brain is the neuron. ${ }^{6}$ Thus, the paucity of CaMPDE expression in glioblastoma multiforme is likely due to the similar low levels of expression in its cell of origin, the astrocyte. Immunohistochemistry studies on fixed tissue support this suggestion.

Another explanation may be that neoplastic changes may have modified the gene of CaMPDE resulting in an altered epitope, and therefore failure to crossreact with the antibody occurred. If the enzyme is not expressed or is altered in some way in glioblastoma multiforme, the function of the enzyme may be altered. This would suggest that in this tumor subset, there would be an elevation in the levels of cAMP. Preliminary results using an EIA method demonstrate that cAMP levels are increased in these tumors (data not shown). It may be possible that the gene for CaMPDE is not being transcribed; or that it is being transcribed, but is somehow in an altered form (with a different function) that our assay failed to recognize.

There is some previously published work that has emphasized the catalytic activity of CaMPDE in a variety of human brain tumors. ${ }^{44}$ The results showed that the CaMPDE activity in tumors was found to be reduced when compared to normal cortical tissue. The reduction in catalytic activity is in contrast with published reports regarding non-central nervous system tumors citing high PDE activity in tumor tissue ${ }^{45,46}$ when compared to normal tissue. There has been no previous attempt to measure the degree of protein expression of the enzyme.

Using the spectrophotometric assay, we demonstrated a marked reduction in the CaMPDE activity in glioblastoma multiforme $(\mathrm{p}<0.001$, Table). These results appear to correlate with the reduction in protein expression as demonstrated with EIA. Ongoing work supports the close correlation between protein expression by EIA and the enzymatic activity.

The inclusion of other tumor types could potentially demonstrate variations in the degree of catalytic activity versus its respective protein expression. If this is true, it may be possible that some patterns may become evident in certain tumor types.

Table 1. Comparison of $\mathrm{Ca}^{2+}$-calmodulin-dependent phosphodiesterase (CaMPDE) activity, using the spectrophotometric method, versus enzyme immune assay CaMPDE protein quantitative results. CaMPDE activity determined after subtraction of PDE activity in the presence of EGTA from the total PDE activity in the presence of $\mathrm{Ca}^{2+}$ and $\mathrm{CaM}(\mathrm{p}<.001)$. Enzyme expression calculated as per "Materials and Methods" using standard curve for determination of total CaMPDE, and then expressed in nmol/g tissue $(\mathrm{p}<.001)$. Normal tissue refers to human brain tissue taken from patients that did not have brain tumors and GBM refers glioblastoma multiforme. All assays were done in triplicate and all results are means with standard error of the mean. Statistical analysis was done by Student $t$-test.

\begin{tabular}{lccc}
\hline $\begin{array}{l}\text { Tissue } \\
\text { Type }\end{array}$ & Cases & $\begin{array}{c}\text { CaMPDE Activity by the Spectrophotometric Method } \\
(\mu \mathrm{mol} / \mathrm{g} \text { tissue) }\end{array}$ & $\begin{array}{c}\text { Enzyme Expression by the Enzyme Immune Assay } \\
\text { (nmol/g tissue) }\end{array}$ \\
\hline Normal Tissue & 4 & $96 \pm 10.4$ & $0.525 \pm 0.093$ \\
GBM Tissue & 6 & $10 \pm 4.2$ & $0.164 \pm 0.069$ \\
\hline
\end{tabular}




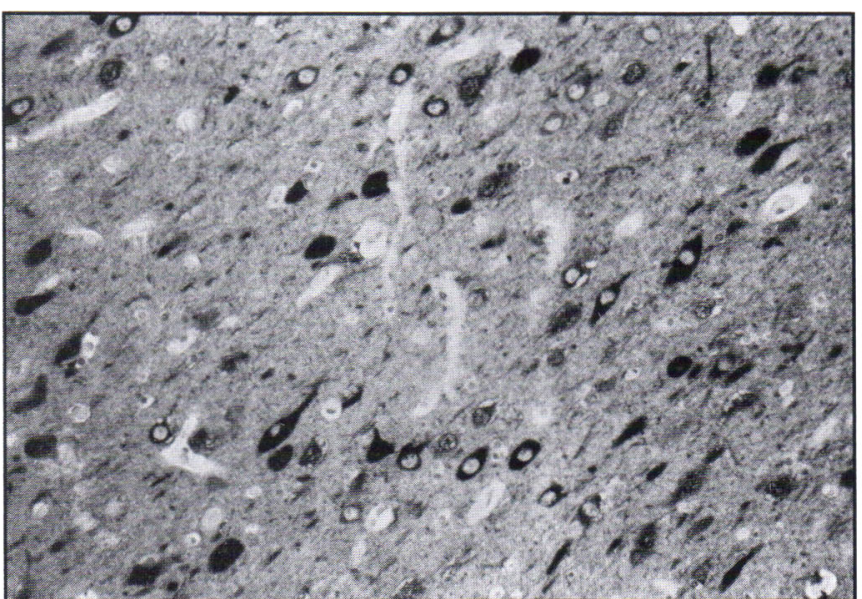

Figure 2: Temporal cortical tissue demonstrating positive staining for

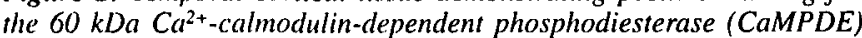
in the cytoplasm and in the axonal process of many neurons. Magnification 400X.

For example if there is low catalytic activity in the presence of high protein expression of PDE in certain cerebral tumors, this could suggest that some substance is responsible for inhibiting the catalytic activity. The opposite could also be true with elevated enzyme activity.

The use of PDE inhibitors would potentially offer another method by which to treat particular subsets of tumors. cAMPdependent protein kinase has been identified as a regulatory element for cell differentiation and proliferation. ${ }^{47}$ cAMP-dependent protein kinase can cause a strong inhibition of cell proliferation and this growth inhibiting process rests mainly with type II isozyme. ${ }^{46}$ In some cited tumor systems, it has been shown that elevation of the type II isozyme has reversed malignancy as expressed by inhibition of cell proliferation along with a return to normal morphology. ${ }^{46}$

The advantage in the use of the EIA method in the case of cerebral tumors is its sensitivity. Spectrophotometric evaluation of CaMPDE activity in human tissue can be difficult if one has a small amount of tissue. Micrograms of tissue can be

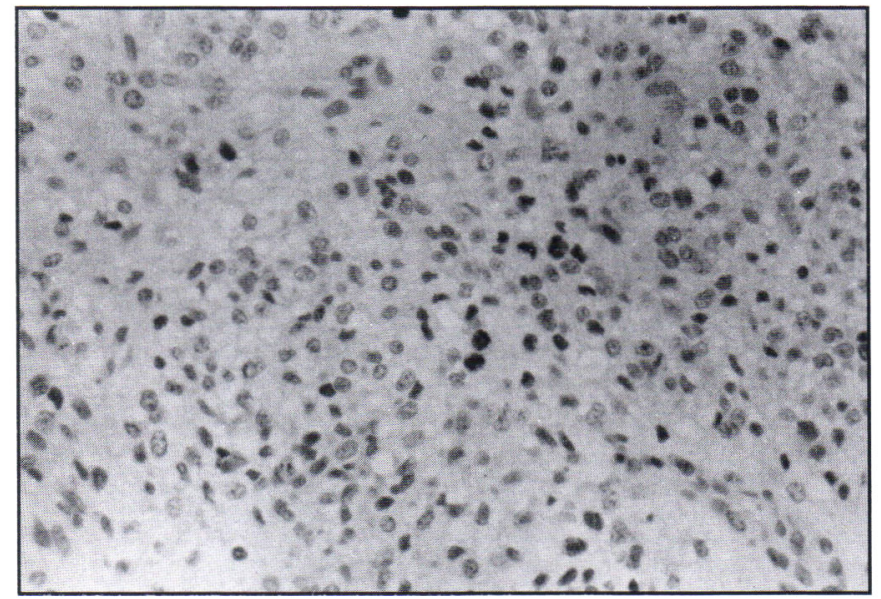

Figure 3: Glioblastoma multiforme section demonstrating absence of staining with the antibody for $\mathrm{Ca}^{2+}$-calmodulin-dependent phosphodiesterase (CaMPDE). No tissue necrosis was present in this region of the tumor. Magnification 250X. used in the EIA method while milligrams to grams of tissue are required in the spectrophotometric method. In experimental systems where repetition is required the EIA method has obvious advantages. The use of the EIA method would preserve the tissue sample for other biochemical or immunohistochemical evaluation.

Another distinct advantage of the EIA over the spectrophotometric method is that the latter method has greater probability of contamination due to endogenous free phosphate which will produce high background in the assay. Therefore, it is essential to dialyze the samples before performing the spectrophotometric assay.

The results clearly demonstrate that the protein expression and the catalytic activity of CaMPDE are siginificantly lower in glioblastoma multiforme than in corresponding normal brain tissue. This is, as previously mentioned, contrary to publications studying other tumor systems. Even though the astrocytes have lower levels of CaMPDE than in normal conditions, rapidly dividing malignant tissue should have elevated levels of PDE. Why it is reduced in cerebral tumors like glioblastoma multiforme needs to be further investigated. The antibody could potentially be used as a marker for other types of cerebral tumors, as it has shown reactivity with cerebral tissue. Further work comparing different types of tumors and non-tumor tissue are progressing in our laboratory at present.

\section{ACKNOWLEDGEMENTS}

This work was supported by the Heart and Stroke Foundation of Saskatchewan. We thank Dr. R.A. Hickie, Department of Pharmacology, College of Medicine, University of Saskatchewan and Dr. L. Clein, Division of Neurosurgery, Royal University Hospital. University of Saskatchewan for reading this manuscript. We thank Mr. Yingchun Tan and Mrs. Connie McGregor for their excellent technical assistance and Mrs. Suniti Saini for typing the manuscript.

\section{REFERENCES}

1. Hickie RA, Walker CM, Croll GA. Decreased cyclic adenosine $3^{\prime}: 5^{\prime}$-monophosphate levels in Morris hepatoma 5123 t.c.(h). Biochem Biophys Res Commun 1974; 59: 167-173.

2. Hickie RA, Jan SH, Datta A. Comparative adenylate cyclase activities in homogenate and plasma membrane fractions in Morris hepatoma 5123 t.c.(h). Cancer Res 1975; 35: 596-600.

3. Hickie RA, Walker CM, Datta A. Increased activity of low K cyclic adenosine $3^{\prime}: 5^{\prime}$ - monophosphate phosphodiesterases in Morris hepatoma 5123 t.c.(h). Cancer Res 1975; 35: 601-605.

4. Hickie RA. Regulation of cyclic AMP and cyclic GMP. In: Morris HP, Criss WE, eds. Morris Hepatomas: Mechanisms of Regulation. New York: Plenum Publishing Corp., 1978: 451488.

5. Halfman DM, Kuo JF. A homogeneous cyclic CMP phosphodiesterase hydrolyzes both pyrimidine and purine cyclic $2^{\prime}: 3^{\prime}$ - and 3':5'-nucleotides. J Biol Chem 1982; 257: 1044-1047.

6. Whitfield JF. Calcium signals and cancer. Clin Rev Oncogenesis 1992; 3: 55-90.

7. Yan C, Bentley JK, Sonnenburg W, et al. Differential expression of the $61 \mathrm{kDa}$ and $63 \mathrm{kDa}$ calmodulin-dependent phosphodiesterases in the mouse brain. J Neurosci 1994; 14: 973-984.

8. Epstein PM, Hachisu R. Cyclic neucleotide phosphodiesterase in normal and leukemic human lymphocytes and lymphoblasts. Adv Cyclic Nuc Prot Phosph 1984; 16: 303-324.

9. Onali P, Strada SJ, Chang L, et al. Purification and characterization of high-affinity cyclic adenosine 5 -monophophate phosphodiesterases from human actue myelogenous leukemic cells. Cancer Res 1985; 45: 1384-1391. 
10. Aleksijec A, Lungnier C, Giron C, et al. Cyclic AMP and cyclic GMP phosphodiesterase activities in Hodgkin's disease lymphocytes. Int J Immunopharmacol 1987; 9: 525-531.

11. Wei J-W, Hickie RA. Decrease activities of cyclic cytidine3':5' monophosphate phosphodiesterase in Morris hepatomas having varying growth rates. Int J Biochem 1983; 15: 789-795.

12. Turnbull JL, Hickie RA. The isolation and characterization of cyclic nucleotide phosphodiesterase from Morris hepatoma 5123 t.c.(h) and rat liver. Int J Biochem 1984; 16: 19-29.

13. Kumar S, Becker G, Prasad KN. Cyclic adenosine 3':5'-monophosphate phosphodiesterase activity in malignant and cyclic adenosine 3':5'-monophosphate-induced "differentiated" neuroblastoma cells. Cancer Res 1975; 35: 82-87.

14. Singer AL, Sherwin RP, Dunn AS, et al. Cyclic nucleotide phosphodiesterase in neoplastic and non-neoplastic mammary tissues. Cancer Res 1976; 36: 60-66.

15. Kakiuchi S, Yamazaki R. Calcium-dependent phosphodiesterase activity and its activating factor (PAF) from brain studies on cyclic 3': 5'-nucleotide phosphodiesterase. Biochem Biophys Res Commun 1970; 41: 1104-1110.

16. Kakiuchi S, Yamazaki R, Teshima Y, et al. Regulation of nucleotide cyclic $3^{\prime}: 5^{\prime}$ monophosphate phosphodiesterase activity from rat brain by a modulator and $\mathrm{Ca}^{2+}$. Proc Natl Acad Sci USA 1973; 70: 3526-3530.

17. Cheung WY. Cyclic 3':5'-nucleotide phosphodiesterase. Determination of activator. Biochem Biophys Res Commun 1970; 38: 533-538.

18. Teo TS, Wang JH. Mechanisms of activation of cyclic adenosine 3':5' monophosphate phosphodiesterase from bovine heart by calcium ions. J Biol Chem 1973; 248: 5950-5955.

19. Sharma RK. Calmodulin-stimulated cyclic nucleotide phosphodiesterase isozymes. Mol Aspects Cell Reg 1988; 5: 265-295.

20. Wang JH, Sharma RK, Mooibroek MJ. Calmodulin stimulated cyclic nucleotide phosphodiesterase. Mol Pharm Cell Reg 1990; 2: $19-59$.

21. Sharma RK, Hickie RA. $\mathrm{Ca}^{2+}$-calmodulin dependent cyclic nucleotide phosphodiesterase (PDEI) In: G Dent, R Klaus and C Schudt, eds. The Handbook of ImmunopharmacologyPhosphodiesterase Inhibitors. London Academic Press, 1996: (in press).

22. Wells JM, Hardman JG. Cyclic nucleotide phosphodiesterases. Adv Cyclic Nucleotide Res 1977; 8: 119-143.

23. Hansen RS, Beavo JA. Purification of two calcium calmodulindependent forms of cyclic nucleotide phosphodiesterase by using conformation-specific monoclonal antibody chromatography. Proc Natl Acad Sci USA 1982; 79: 2788-2792.

24. Sharma RK. Phosphorylation and characterization of bovine heart calmodulin-dependent phosphodiesterase. Biochemistry 1991; 30: 5964-5968.

25. Sharma RK, Wang JH. Purification and characterization of bovine lung calmodulin-dependent cyclic nucleotide phosphodiesterase. J Biol Chem 1986; 261: 14160-14166.

26. Sharma RK, Adachi AM, Adachi K, et al. Demonstration of bovine brain calmodulin-dependent cyclic nucleotide phosphodiesterase isozyme by monoclonal antibodies. J Biol Chem 1984; 259: 9248-9254.

27. Purvis K, Olsen A, Hansson V. Calmodulin-dependent cyclic nucleotide phosphodiesterase in the immature rat testis. J Biol Chem 1981; 256: 11434-11441.

28. Vandermeers A, Vandermeers-Piret MC, Rathe J, et al. Purification and kinetic properties of two soluble forms of calmodulin-dependent cyclic nucleotide phosphodiesterase from rat pancreas. Biochem J 1983; 211: 341-347.
29. Rossi P, Giorgi M, Geremia R, et al. Testis specific calmodulindependent phosphodiesterase. A distinct high affinity cAMP isozyme immunologically related to brain calmodulin-dependent cGMP phosphodiesterase. J Biol Chem 1983; 263: 15521-15527.

30. Sharma RK, Kalra J. Characterization of calmodulin-dependent cyclic nucleotide phosphodiesterase isozymes. Biochem J 1994; 299: 97-100.

31. Sharma RK, Wang JH. Differential regulation of calmodulin-dependent cyclic nucleotide phosphodiesterase isozyme by cyclicAMP dependent protein kinase and calmodulin dependent phosphatase. Proc Natl Acad Sci USA 1985; 82: 2603-2607.

32. Florio VA, Sonnenburg WK, Johnson R, et al. Phosphorylation of the $61 \mathrm{kDa}$ calmodulin-stimulated cyclic nucleotide phosphodiesterase at serine 120 reduces its affinity for calmodulin. Biochemistry 1994; 33: 8948-8954.

33. Sharma RK, Wang JH. Regulation of $63 \mathrm{kDa}$ subunit containing isozyme of bovine brain calmodulin-dependent cyclic nucleotide phosphodiesterase by a calmodulin-dependent protein kinase. J Biol Chem 1986; 261: 1322-1328.

34. Hashimoto Y, Schworer CM, Colbran RJ, et al. Autophosphorylation of $\mathrm{Ca}^{2+} / \mathrm{calmodulin}$ protein kinase Il: effects on total and $\mathrm{Ca}^{2+}$-independent activities and kinetic parameters. J Biol Chem 1987; 262: 8051-8055.

35. Zhang GY, Wang JH, Sharma RK. Purification and characterization of bovine brain calmodulin-dependent protein kinase II. The significance of autophosphorylation in the regulation of $63 \mathrm{kDa}$ calmodulin-dependent cyclic nucleotide phosphodiesterase isozyme. Mol Cell Biochem 1993; 22: 159-169.

36. Sharma RK, Wang JH. Isolation of bovine brain calmodulin-dependent cyclic nucleotide phosphodiesterase isozymes. Methods Enzymol 1988; 159: 582-594.

37. Voller A, Bartlett A, Bidwell DE. Enzyme immune assay with special reference to ELISA technique. J Clin Pathol 1978; 31: 507 520.

38. Sharma RK, Wang JH. Preparation and assay of the $\mathrm{Ca}^{2+}$-dependent modulator protein. Adv Cyclic Nucleotide Res 1979; 10: 187 198.

39. Laemmli UK. Cleavage of structural proteins during the assembly of the head of bacteriophage T4. Nature 1970; 227: 680-685.

40. Bradford MM. A rapid and sensitive method for the quantitation of microgram quantities of protein utilising the principles of protein-dye binding. Anal Biochem 1976; 72: 248-254.

41. Sharma RK. Purification and characterization of novel calmodulinbinding protein from cardiac muscle. J Biol Chem 1990; 265: 1152-1157.

42. Russell DS, Rubenstein LS. Pathology of Tumors of the Nervous System. Williams and Wilkins, 5th ed, 1990: 219-246.

43. Harsh GR, Wilson CB. Neuroepithelial Tumors of the Adult Brain, Youmans Neurological Surgery. New York W.B. Saunders, 1989; 5: 3040-3136.

44. Brostrom C, Wolf D. Calcium-dependent cyclic nucleotide phosphodiesterase from glial tumor cells. Arch Biochem Biophys 1974; 65: 715-727.

45. Stefanovich V, Ambrus J, Karakousis C, et al. Cyclic nucleotide phosphodiesterases in normal and malignant human tissue. $\mathrm{J}$ Medicine 1981; 12: 243-250.

46. Whitfield JF, Boynton AL, MacManus JP, et al. The regulation of cell proliferation by calcium and cyclic AMP. Mol Cell Biochem 1979; 27: 155-179.

47. Schuller $\mathrm{H}$. The signal transduction model of carcinogenesis. Biochem Pharm 1991; 42: 1511-1523. 